\title{
EXCHANGE RATE REGIMES AND THE EXTENSIVE MARGIN OF TRADE
}

\author{
Paul R. Bergin \\ Ching-Yi Lin \\ Working Paper 14126 \\ http://www.nber.org/papers/w14126
}

\author{
NATIONAL BUREAU OF ECONOMIC RESEARCH \\ 1050 Massachusetts Avenue \\ Cambridge, MA 02138 \\ June 2008
}

The views expressed herein are those of the author(s) and do not necessarily reflect the views of the National Bureau of Economic Research.

NBER working papers are circulated for discussion and comment purposes. They have not been peerreviewed or been subject to the review by the NBER Board of Directors that accompanies official NBER publications.

(C) 2008 by Paul R. Bergin and Ching-Yi Lin. All rights reserved. Short sections of text, not to exceed two paragraphs, may be quoted without explicit permission provided that full credit, including $\odot$ notice, is given to the source. 
Exchange Rate Regimes and the Extensive Margin of Trade

Paul R. Bergin and Ching-Yi Lin

NBER Working Paper No. 14126

June 2008

JEL No. F4

\begin{abstract}
$\underline{\text { ABSTRACT }}$
This paper finds that currency unions and direct exchange rate pegs raise trade through distinct channels. Panel data analysis of the period 1973-2000 indicates that currency unions have raised trade predominantly at the extensive margin, the entry of new firms or products. In contrast, direct pegs have worked almost entirely at the intensive margin, increased trade of existing products. A stochastic general equilibrium model is developed to understand this result, featuring price stickiness and firm entry under uncertainty. Because both regimes tend to reliably provide exchange rate stability over the horizon of a year or so, which is the horizon of price setting, they both lead to lower export prices and greater demand for exports. But because currency unions historically are more durable over a longer horizon than pegs, they encourage firms to make the longer-term investment needed to enter a new market. The model predicts that when exchange rate uncertainty is completely and permanently eliminated, all of the adjustment in trade should occur at the extensive margin.
\end{abstract}

\author{
Paul R. Bergin \\ Department of Economics \\ University of California, Davis \\ One Shields Ave. \\ Davis, CA 95616 \\ and NBER \\ prbergin@ucdavis.edu \\ Ching-Yi Lin \\ University of California, Davis \\ Department of Economics \\ One Shield Avenue \\ Davis, CA 95616 \\ chylin@ucdavis.edu
}




\section{Introduction}

A primary rationale given by many countries adopting regimes of exchange rate stabilization, be it a peg or a full currency union, is the goal of promoting more international trade. Despite a long literature failing to show a robust linkage between exchange rate variance and trade, Rose (2000) stimulated a great deal of interest by finding that the adoption of a currency union historically has tended to raise bilateral trade by a large amount. ${ }^{1}$ Subsequent literature generally has supported the statistical significance, if not the magnitude of this result. ${ }^{2}$ In addition, Klein and Shambaugh (2006) find that adopting a direct peg, in which a country fixes its exchange rate to a particular trading partner, also has a significant effect to raise bilateral trade.

This paper studies the effect of exchange rate regimes on bilateral trade by decomposing trade into its extensive and intensive margins, where the extensive margin is an increase in the number of firms or products, and the intensive margin is a rise in the value of trade by existing firms or products. Recent research in trade theory has emphasized this distinction, as it has implications for the welfare gains of trade and resource allocation. The empirical section of this paper conducts panel gravity regressions, analogous to those of Rose (2000) and Klein and Shambaugh (2006), but it considers three distinct independent variables: bilateral trade flows, the extensive margin of bilateral trade, and the intensive margin. The extensive and intensive margins are measured using the NBER/UN data base prepared by Robert Feenstra and Robert Lipsey, which records bilateral trade flows at a 4-digit disaggregated goods level. This data set covers the years 1962-2000, so it does not include the

\footnotetext{
${ }^{1}$ Regarding exchange rate stability, see Cushman (1983) and Klein (1990), for example.

${ }^{2}$ There is an extensive literature on this subject. For a sampling of supporting evidence see Rose and van Wincoop (2001), Glick and Rose (2002), and Frankel and Rose (2002). For a sampling of critiques see Persson (2001) and Nitsch (2002). See Baldwin (2006) for a useful survey.
} 
recent experience of the European Monetary Union. Consequently the results for currency unions, like those in Rose (2000), are based on countries that are mainly small or poor, so implications are not directly applicable to EMU members. The exchange rate regime classifications used are from Klein and Shambaugh (2007).

The empirical work first confirms two stylized facts from previous work: both currency unions and direct pegs raise trade flows, and the effect is somewhat larger for currency unions than for pegs. Of greater novelty are two additional stylized facts that are uncovered. Currency unions have a large and statistically significant effect at the extensive margin, but a small and insignificant effect at the intensive margin. In contrast, direct pegs exhibit just the opposite pattern: a small and insignificant effect at the extensive margin, but a significant effect at the intensive margin. Our overall empirical conclusion, then, is that while currency unions and direct pegs both raise trade flows, they appear to work through distinct channels. These findings offer some new insight into the role of exchange rate regimes in facilitating trade, which are useful in discriminating among alternative theories. ${ }^{3}$

The theoretical section of this paper develops a potential explanation for these empirical findings. It builds upon developments in international macroeconomics, in modeling how exchange rate uncertainty affects the price-setting of firms under price stickiness. But it also utilizes some recent developments in trade theory, which model firm entry decisions in the face of fixed costs. ${ }^{4}$ As a result, this paper is among the very first to model how exchange rate

\footnotetext{
${ }^{3}$ Related to this work, Baldwin and Di Nino (2006), Bergin and Glick (2007), and Kehoe and Ruhl (2002) find in studies of the specific case of the euro area that there appears to be a significant effect on the extensive margin. This study agrees with this point, though for a different set of countries, and it goes on to find a contrasting result for direct pegs.

${ }^{4}$ Entry here can be interpreted either as additional firms or additional product lines. We do not explicitly model multi-product firms, as done in Bernard et al. (2006).
} 
uncertainty affects firm entry decisions under sticky prices. ${ }^{5}$ The model is a stochastic general equilibrium monetary model with two symmetric countries. It specifies that prices must be set before the monetary shocks driving exchange rates are known, and that the entry decision must be made a period prior to this. Motivated by empirical evidence, we assume that while both pegs and currency unions are credible in eliminating exchange rate volatility over the horizon that prices are pre-set, only a currency union is credible for the longer horizon over which entry decisions must be determined.

As a result, both regimes lower the riskiness of foreign sales when the firm is setting price, which results in lower export prices and higher export sales, consistent with our first empirical fact. However, the existence of a peg when a firm is deciding on entry is not very informative about the exchange rate behavior in the later period when export sales take place. As a result, only the currency union encourages more entry relative to a freely floating exchange rate regime. This is consistent with the last two of our empirical facts above. In fact, the model predicts that 100 percent of the rise in trade volume when a currency union eliminates exchange rate uncertainty comes at the extensive margin, with no impact on the intensive margin. This is somewhat surprising, since one might expect the risk premium in prices, used by firms to hedge against exchange rate uncertainty in price setting, could also

\footnotetext{
${ }^{5}$ This project differs from other prominent research in the field. Ghironi and Melitz (2005) show how to combine recent developments in trade theory with a macroeconomic model. But it focuses on the dynamic response to real shocks; it did not include money, nominal exchange rates, nor the nominal rigidities needed to study the real effects of exchange rate regimes. Naknoi (2007) is the first to have a monetary model with endogenous tradability and nominal stickiness. However, it studies an entirely different issue, trying to explain the source of exchange rate variability, rather than how exchange rate risk affects entry decisions. Kumhof, Laxton, and Naknoi (2007) is the first to integrates trade theory and trade frictions into a monetary model which is usable for policy analysis, doing so in a very rich dynamic setting. However, this paper again studies a different issue than the present project, as it focuses on how exchange rate movements induce costly adjustments in trade flows, where the real costs of adjustment impose a welfare loss; it does not study the issue of special interest here, regarding how exchange rate variability has level effects on the mean level of trade.
} 
help hedge against the effects of risk on the entry decision. But this is not the case. Finally, the fact that currency unions induce a larger entry of new varieties interacts with love for variety in preferences to stimulate more expenditure on exported goods than under a peg, which results in a larger impact of currency unions on overall trade flows. This is consistent with the second of our four empirical facts.

In related work, Baldwin et al. (2005) proposes a model of how a reduction in exchange rate uncertainty under a currency union stimulates the extensive margin. Our paper differs in that it models the effect of uncertainty from first principles, tracing how it affects price setting and entry decisions. ${ }^{6}$ In addition, our model is able to distinguish between the effects of reducing exchange rate uncertainty through direct pegs versus currency unions.

\section{Empirical Analysis}

The study uses a panel dataset which covers 148 countries' bilateral exports at an annual frequency from 1973 to 2000. Our range of counties and the end date of our sample are determined by the availability of the disaggregated trade data needed for us to measure the extensive margin. These data come from the NBER-UN World Trade Data set, developed by Rob Feenstra and Robert Lipsey, documented in Feenstra et al. (2005). This data set computes annual bilateral trade flows at the four-digit Standard International Trade Classification, by performing a series of adjustments on $\mathrm{UN}$ trade $\mathrm{data}^{7}$. For data on exchange rate regime classifications, we use the classifications in Klein and Shambaugh (2006, 2007), hereafter

\footnotetext{
${ }^{6}$ In contrast, Baldwin et al. (2005) introduces exchange rate uncertainty in a more ad hoc manner by introducing the variance of exchange rates as a term in a firm loss function. Further, he does not study how uncertainty affects trade and entry by affecting price-setting decisions.

${ }^{7}$ It is noted that the data purchased from the UN for 1984-2000 only had values in excess of $\$ 100,000$, for each bilateral flow. To be consistent, the cutoff of exports in this study is set as $\$ 100,000$, which implies that goods are considered nontradable if an export value of the category is less than $\$ 100,000$.
} 
referred to as KS. Although the bilateral trade data starts earlier than 1973 (in 1962), we follow KS in focusing on the post Bretton Woods period. As they note, the pegs in Bretton Woods were part of a multilateral system with extensive capital controls, and so are quite different from more contemporary unilateral pegs. Nonetheless, we will show in supplementary tables that our results are quite robust to a longer sample range. Geographic data needed for our regressions come from the data set of Andrew Rose (Rose, 2004).

The definition of a peg in this data set requires that the bilateral exchange rate stays within a $2 \%$ band at the end of each month the entire year, and direct peg occurs when it can be identified in addition that one country pegs to a particular base country. In any one year about $50 \%$ of the countries in the sample are involved in a peg with some other country. Many of these are a developing country pegging to an industrialized one. There is a great deal of regime switching among these countries. Klein and Shambaugh (2007) note that $44 \%$ of pegs last for only one year. Interestingly, there is also a high rate of regime change among floats; 36 percent of floats spells also last for only one year.

The definition of a currency union is a strict one, as in Rose (2000), that currencies trade at a 1 to 1 rate. As noted in KS, the currency unions usually involve countries that are small or poor. In our sample there are 65 country pairs that show a currency union relationship. ${ }^{8}$ These relationships are much more stable than pegs, in that only 9 of the 65 country pairs exhibited a change in regime during the entire 28 year sample.

Following Hummels and Klenow (2005), the extensive margin is measured in a manner consistent with consumer price theory by adapting the methodology in Feenstra (1994). The extensive margin of exports from country $j$ to country $m$, denoted by $E M_{m}^{j}$ is defined as

\footnotetext{
${ }^{8}$ The list of countries involved in these pairs are: Australia, Bangladesh, Benin, Burkina Faso, Central African Republic, Chad, Congo, Cote Divoire, Dominican Republic, Gabon, Guatemala, Guinea Bissau, India, Ireland, Kiribati, Liberia, Madagascar, Mauritania, Niger, Panama, Senegal, Togo, U.K., USA.
} 


$$
E M_{m}^{j}=\frac{\sum_{i \in I_{m}^{j}} X_{m, i}^{W}}{X_{m}^{W}}
$$

where $X_{m, i}^{W}$ is the export values from the world to country $j$ of product category $I, I_{m}^{j}$ is the set of observable categories in which country $j$ has positive exports to country $m$, and $X_{m}^{W}$ is the aggregate value of world exports to country $m$. The extensive margin is a weighted count of country $j$ 's categories relative to all categories exported to country $m$, where the categories are weighted by their importance in world's exports to country $m$.

The corresponding intensive margin of exports from country $j$ to country $m$, denoted by $I M_{m}^{j}$, is defined as

$$
I M_{m}^{j}=\frac{X_{m}^{j}}{\sum_{i \in I_{m}^{j}} X_{m, i}^{W}}
$$

where $X_{m}^{j}$ is the total export value from country $j$ to country $m$. The intensive margin is measured as $j$ 's export value relative to the weighted categories in which country $j$ exports to country $m$. Therefore, multiplying the intensive margin by the extensive margin produces country j's share of world exports to country m, denoted by EXShare ${ }_{m}^{j}$,

$$
\operatorname{EXShare~}_{m}^{j}=\frac{X_{m}^{j}}{X_{m}^{W}}=E M_{m}^{j} I M_{m}^{j}
$$

The categories of goods exported might differ across exporters and change over time. With the same level of share of world exports to country $m$ at time $t$, the measurement implies that country $j$ would have a higher extensive margin measure if it exports many different categories of products to country $m$, whereas, it would have a higher intensive margin if country $j$ only export a few categories to country $m$. 
Separate panel regressions are run by regressing the extensive margin, the intensive margin, and the exporter's total share on the exchange rate regime variables, as well as the standard set of gravity model variables. The benchmark regressions take the form:

$$
\begin{aligned}
& Y_{j m, t}=\beta_{0}+\beta_{1} C U_{j m, t}+\beta_{2} \operatorname{Peg}_{j m, t}+\beta_{3} I d P e g_{j m, t}+\beta_{4} e x \operatorname{var}_{j m, t}+\lambda X_{j m, t}+\gamma F_{j m}+\phi t \\
& +\kappa \exp +\omega i m p+\varepsilon_{j m, t}
\end{aligned}
$$

The model is estimated based on the ordinary least squares with robust standard errors clustered in export pair level, where $j$ is the exporter and $m$ is the importer. The dependent variables $\left(Y_{j m, t}\right)$ will be either the logarithm of country $j$ 's extensive margin of exports to country $m$, the logarithm of country $j$ 's intensive margin, or the logarithm of share of world exports. Regressors include dummies for the exchange rate regime: $C U_{j m, t}$ for a currency union, $P e g_{j m, t}$ for and direct peg, and $I_{d P e g}$ fm,t for an indirect peg. The regressor $e x \mathrm{var}_{j m, t}$ is a measure of volatility of the nominal exchange rate between countries $j$ and $m$, which is the standard deviation of the first difference of the logarithm of the monthly exchange rate between the two countries. Next, $X_{j m, t}$ is a set of variables that vary over time, which includes the logarithm of real GDP per capita of exporter $j$ relative to real GDP per capita of all countries who export to importer $m$, logarithm of exporter $j$ 's population relative to real GDP per capita of all countries who export to importer $m$, a dummy variable indicating whether the two countries had a free trade agreement at time $t$, and a dummy variable for pairs currently in colonial relationship. $F_{j m}$ is a set of variables that do not vary over time, such as the logarithm of distance between country $j$ and $m$, a common language dummy, a land border dummy, and a dummy for pairs ever in colonial relationship. Also included is a time effect, $t$, to control for time-specific factors such as global shocks or business cycles. 
To avoid omitting variables that may affect bilateral trade, two vectors of dummy variables, exp and imp, are included indicating exporter and importer fixed effects. As Anderson and van Wincoop (2003) proposed, country effects are included as controls for multilateral resistance. We decided to use separate country fixed effects for each country as exporter and importer, because in contrast with the related literature on trade flows, our dependent variable specifies the direction of trade. ${ }^{9}$

Initial results are reported in Table 1, covering the sample with country fixed effects from 1973 to 2000. Currency union has a highly statically significant effect to raise both overall exports and the extensive margin of exports, but an insignificant (small negative) effect at the intensive margin. In contrast, a direct peg has a significant effect to raise overall trade and the intensive margin, but the effect at the extensive margin is insignificant. The coefficients for currency union imply that a currency union would raise the export share by $122 \%$ because of a $149 \%$ increase in the extensive margin. ${ }^{10}$ So all of the rise in trade comes at the extensive margin. A peg can increase export share by 26\%, which comes from $25 \%$ increase in the intensive margin of exports. So virtually all of the rise in trade comes at the intensive margin. In summary, there are four facts observed for this data set. First, both exchange rate regimes raise bilateral trade, but second, currency unions have a larger effect. Third, currency unions work at the extensive margin, while fourth, direct pegs work at the intensive margin.

\footnotetext{
${ }^{9}$ Country-pair fixed effects could be useful if trade resistance is bilateral rather than multilateral in nature. But we do not implement this in the estimation, as it would eliminate cross-sectional variation in the panel and leaving only time-series variation. Country pairs that have no regime switch for the entire sample period do not yield information in the estimate. In the study of the impacts of currency union, we can even less afford to sacrifice cross-sectional information. There are 65 country pairs ever had a currency union, but only 9 of them had a regime switch in the sample period.

${ }^{10}$ The export share is 2.22 times higher $(122 \%)$ because $\exp (0.796)=2.22$; the extensive margin is 2.49 times higher $(149 \%)$ because $\exp (0.913)=2.49$.
} 
Regarding other coefficients, exchange rate volatility does not have a statistically significant effect on overall trade, echoing results in other studies. The coefficients on indirect peg are negative, which is somewhat surprising. The standard gravity variables are generally significant and of the expected sign.

Anderson and van Wincoop (2004) note that multilateral resistance could change over time, indicating that the country fixed effects used in the previous regression are not sufficient controls. Table 2 reports results when we use country-year fixed effects, where separate country fixed effects are included for each year in the panel regression. We will follow Klein and Shambaugh (2006) in using this specification as our benchmark result. Results are very similar to those reported above, where currency union has a significant effect to raise overall trade and the extensive margin, and direct pegs have significant effects on overall trade and the intensive margin. However, the magnitude of currency union impacts are somewhat smaller. Translating coefficients, a currency union raises the overall trade share by $84 \%$, raises the extensive margin $84 \%$ and raises the intensive margin $0 \%$. A direct peg raises overall trade share by $25 \%$, the extensive margin by $0 \%$, and the intensive margin by $25 \%$. Again we see that while both exchange rate regimes raise overall trade, they are entirely distinct in terms of the margins of trade through which they work.

Next, consider robustness of results to controlling for endogeneity with instrumental variables estimation. One might be concerned that exchange rate regimes could respond to an anticipated change in bilateral trade, rather than bilateral trade responding to a change in the exchange rate regime. The instrumental variable used here is the same as in Klein and Shambaugh (2006), the percentage of countries in country $j$ 's region that are directly pegged with country $i$ for a given pair of country $i$ and $j$. The instrument predicts whether a country 
pegs its currency, and thereby can indirectly affect trade, but it will have no direct impact on trade, itself. Table 3 shows that results are very similar to those reported above. In particular, the pattern of significance for currency unions and pegs is unchanged. The magnitude of the currency union coefficient in Table 3 is very close to that from Table 1, and the direct peg coefficient is about twice as large as in Table 1.

Finally, Table 4 shows results for estimating over the date range prior to Bretton Woods, 1962-2000. Results again are very similar. The only exception being that in the case of IV estimation, the direct peg loses its significance on the overall export share.

\section{Theoretical Analysis}

The purpose of this section is to study theoretically the effect of exchange rate uncertainty on firms' decisions to enter export markets. We use a stochastic general equilibrium model of two symmetric countries with price stickiness and fixed costs of entry into both domestic and export markets. Uncertainty comes from monetary shocks in both countries, and we assume balanced trade. ${ }^{11}$ To permit a closed form solution for the number of firms entering under uncertainty, the model will abstract from firm heterogeneity; however, the concluding section will conjecture on heterogeneity's likely implications for the paper's results. A key element in this analysis will be prices that need to be preset before firms observe the shocks determining exchange rates. Given uncertain valuation of profits from foreign sales, and assuming preferences where consumption and leisure are substitutes, firms will hedge against risk by setting higher prices on exported goods. This risk premium in prices has implications similar to

\footnotetext{
${ }^{11}$ All our results hold also under the alternative assumption of complete asset markets, which replaces the balanced trade condition with the following risk sharing condition: $u_{c t_{2}} / u^{\prime}{ }_{c t_{2}}=E_{t_{2}} P_{t_{1}}^{*} / P_{t_{1}}$. This implies that our results are robust to including assets usable for exchange rate hedging.
} 
iceberg trade costs in more standard trade models. Higher export prices will discourage demand for traded goods and reduce the volume of trade. This effect applies equally to all exchange rate regimes that lower exchange rate volatility, both currency union and direct peg alike. To distinguish between these two regimes, we draw on the empirical observation that about half of new pegs do not survive more than one year, whereas currency unions tend to last many years. We model the effect this has on entry decisions, by assuming that the fixed cost must be paid earlier than price setting, when there is still uncertainty about the exchange rate regime that will prevail when sales take place.

For the sake of clarity in describing the sequence of events and information sets, we specify a three period model. The final period $\left(t_{2}\right)$ is when production and all sales take place. This is the period where the shocks are revealed, which determine the equilibrium values of the exchange rate, wages, and production. In the period previous $\left(t_{1}\right)$, firms must choose their prices for domestic and foreign sales, based upon their expectations for shocks and equilibrium values the subsequent period. The firms' decision to enter a market must be made in the period previous to this $\left(t_{0}\right)$, based upon their expectations conditional on information in this period. We assume that currency unions adopted in period $t_{0}$ can be expected to continue to exist in periods $t_{1}$ and $t_{2}$. By contrast, we assume that direct pegs adopted in period $t_{0}$ last through period $t_{1}$, but then are expected to fail by the time period $t_{2}$ begins. Likewise, direct pegs adopted in period $t_{1}$ are expected to last to the end of period $t_{2}$. To permit an analytical solution, we assume firm expectations assign a zero probability to a direct peg adoption exante. $^{12}$

\footnotetext{
${ }^{12}$ Given that Klein and Shambaugh (2007) show that a new peg has a 44\% chance of failing after its first year, a better assumption would be to model agent expectations for a corresponding probability distribution of a peg and float in year $t_{2}$. But this assumption proved intractable for an analytical solution comparing across regimes.
} 
While we use a three-period characterization of the model for clarity, an equivalent characterization (under i.i.d. shocks) that more naturally maps into our empirical study would be as an infinite horizon of annual observations. Prices are chosen at the beginning of each year, for sales later that same year, and entry decisions are made one year ahead of time. Pegs adopted at the beginning of the year are expected to last until the end of the year, but not until the next year. In this characterization, period $t_{2}$ corresponds to the end of the year, $t_{1}$ to the beginning of the year, and $t_{0}$ to the end of the previous year.

In the notation below, the dating convention will be to date variables by the period in which they are determined.

\subsection{Households}

There is a continuum of identical households in each of the two countries, designated home and foreign, and the population in each country is normalized to one. A representative household in the home country consumes $n_{H}$ varieties of home goods, and $n_{F}$ varieties of goods exported from the foreign country. He supplies labor, receives profits from owning an equal proportion of domestic firms, and holds home money through a cash-in-advance constraint. The representative household of the Home country maximizes the expectation of utility

$$
U\left(C_{t_{2}}, l_{t_{2}}\right)
$$

in period 2, where $C$ is aggregate consumption, $l$ is leisure, and where it is assumed that consumption and leisure are substitutes. Aggregate consumption is defined as a nested CES aggregator, with a potentially distinct elasticity between home and foreign goods aggregates $(\phi)$, and among varieties from a given country $(\mu)$. 


$$
C_{t_{2}}=\left(\left(\frac{1}{2}\right)^{\frac{1}{\phi}}\left(C_{H_{2}}\right)^{\frac{\phi-1}{\phi}}+\left(\frac{1}{2}\right)^{\frac{1}{\phi}}\left(C_{F t_{2}}\right)^{\frac{\phi-1}{\phi}}\right)^{\frac{\phi}{\phi-1}}
$$

where

$$
C_{H_{2}} \equiv n_{H t_{2}}{ }^{\gamma-\frac{\mu}{\mu-1}}\left(\int_{0}^{n_{\mathrm{Ht}}}\left(C_{\mathrm{Ht}_{2}}(i)\right)^{\frac{\mu-1}{\mu}} d i\right)^{\frac{\mu}{\mu-1}}=n_{\mathrm{Ht}_{2}}{ }^{\gamma} C_{\mathrm{Ht}_{2}}(i)
$$

and

$$
C_{F t_{2}} \equiv n_{F t_{2}}{ }^{\gamma-}-\frac{\mu}{\mu-1}\left(\int_{0}^{n_{F t}}\left(C_{F t_{2}}(j)\right)^{\frac{\mu-1}{\mu}} d j\right)^{\frac{\mu}{\mu-1}}=n_{F t_{2}}^{\gamma} C_{F t_{2}}(j)
$$

for homogeneous firms. Following Benassy (1996), the parameter $\gamma$ indicates the degree of love for variety, in that $\gamma-1$ represents the marginal utility gain from spreading a given amount of consumption on a basket that includes one additional good variety in a symmetric equilibrium.

Households hold and receive only domestic currency from the government. The cash-inadvanced constrain is ${ }^{13}$

$$
P_{t_{1}} C_{t_{2}}=M_{t_{2}}
$$

The budget constraint of the household in the Home country is presented by

$$
P_{t_{1}} C_{t_{2}}=W_{t_{2}} L_{t_{2}}+\Pi_{t_{2}}=M_{t_{2}}
$$

where $W$ is the nominal wage rate and $\Pi$ is the household's ownership income from the activity of firms. The first order condition of the consumer's problem yields the labor supply relation,

$$
u_{c t_{2}} \frac{W_{t_{2}}}{P_{t_{1}}}=u_{l t_{2}}
$$

\footnotetext{
${ }^{13}$ The government is assumed to impose an identical tax at the end of the period after all transactions are made. Money will then serve as a unit of account in each country, but does not have any distortionary effect by itself.
} 
Price indexes are defined as usual for each range of varieties, in correspondence to the consumption indices above:

$$
\begin{aligned}
& P_{t_{2}}=\left(\frac{1}{2}\left(P_{H t_{2}}\right)^{1-\phi}+\frac{1}{2}\left(P_{F t_{2}}\right)^{1-\phi}\right)^{\frac{1}{1-\phi}} \\
& P_{H t_{1}}=n_{H t_{0}}-\left(\gamma-\frac{\mu}{1-\mu}\right)\left(\int_{0}^{n_{H t_{0}}}\left(p_{H t_{1}}(i)\right)^{1-\mu} d i\right) \frac{1}{1-\mu}=n_{H t_{0}}{ }^{1-\gamma} P_{H t_{1}}(i) \\
& P_{F t_{1}}=n_{F t_{0}}-\left(\gamma-\frac{\mu}{1-\mu}\right)\left(\int_{0}^{n_{F t_{0}}}\left(p_{F t_{1}}(i)\right)^{1-\mu} d i\right)^{\frac{1}{1-\mu}}=n_{F t_{0}}{ }^{1-\gamma} P_{F t_{1}}(i)
\end{aligned}
$$

for homogeneous firms, where $P$ is the aggregate domestic country price level, $P_{H}$ is the price index of the home good, $P_{F}$ is the price (to domestic residents) of the imported foreign good. These imply relative demand functions for domestic residents:

$$
\begin{aligned}
& C_{H_{t_{2}}} / C_{t_{2}}=\frac{1}{2}\left(P_{H_{t_{1}}} / P_{t_{1}}\right)^{-\phi} \\
& C_{F_{t_{2}}} / C_{t_{2}}=\frac{1}{2}\left(P_{F_{t_{1}}} / P_{t_{1}}\right)^{-\phi}
\end{aligned}
$$

and

$$
\begin{aligned}
& c_{H t_{2}}(i) / C_{H t_{2}}=\left(p_{H_{t_{1}}}(i) / P_{H t_{1}}\right)^{-\mu} n_{H t_{0}}^{\mu(\gamma-1)-\gamma}=n_{H t_{0}}^{-\gamma} \\
& C_{F t_{2}}(i) / C_{F t_{2}}=\left(p_{F_{t_{1}}}(i) / P_{F t_{1}}\right)^{-\mu} n_{F t_{0}}^{\mu(\gamma-1)-\gamma}=n_{F t_{0}}^{-\gamma} .
\end{aligned}
$$

Analogous conditions apply to the foreign country. Note that under symmetry $n_{H t_{0}}=n_{F_{t_{0}}}^{*}$ and $n_{H t_{0}}^{*}=n_{F_{t_{0}}}$.

\subsection{Firms’ Behavior}

Production technology is assumed to be linear in labor: 


$$
y_{\mathrm{Ht}_{2}}(i)=A L_{\mathrm{Ht}_{2}} \text {, }
$$

where $A$ represents productivity, which is assumed deterministic and homogeneous across firms. Firms pay an equilibrium wage rate $W$ for each unit of labor. To produce for domestic sale, firms must also pay a fixed cost, $F$, in domestic labor units. To export, firms pay an iceberg cost, $\tau$, as well as committing to pay a fixed cost, $F^{*}$, which is in units of domestic labor. Firms must pre-commit to paying both types of fixed costs in period $t_{0}$. It is assumed that the fixed cost of entering the domestic market is lower than that of entering the export market $\left(F<F^{*}\right)$, due to the additional costs of language, product standards, legal barriers, and transactions costs associated with currency conversion.

Firms must set prices in the currency of the buyer in period $t_{1}$ for sales in period $t_{2}$, before knowing the realization of monetary shocks. Each firm would maximize the expected market value of total nominal profits from domestic and exported markets. Since households are the owners of firms, uncertain profits across states are discounted using the marginal utility of consumption.

A home firm's problem is to maximize its expected profits:

$$
\begin{aligned}
& \max E_{t_{1}}\left[u_{c} \pi_{H}(i)+u_{c} \pi_{H}^{*}(i)\right] \\
& \pi_{H t_{2}}(i)=\left(p_{H t_{1}}(i)-\frac{W_{t_{2}}}{A}\right) c_{H t_{2}}(i)-W_{t_{2}} F \\
& \pi_{H t_{2}}^{*}(i)=\left(s_{t_{2}} p_{H t_{2}}^{*}(i)-\frac{W_{t_{2}}}{A(1-\tau)}\right) c_{H t_{2}}^{*}(i)-W_{t_{2}} F^{*} .
\end{aligned}
$$

Using demand conditions from above, the optimal price setting conditions are (see appendix for derivations): 


$$
\begin{aligned}
& p_{H t_{1}}(i)=\left(\frac{\mu}{\mu-1}\right) \frac{E_{t_{1}}\left[u_{c t_{2}} M_{t_{2}} \frac{W_{t_{2}}}{A}\right]}{E_{t_{1}}\left[u_{c t_{2}} M_{t_{2}}\right]} \\
& p_{H t_{1}}^{*}(i)=\left(\frac{\mu}{\mu-1}\right) \frac{E_{t_{1}}\left[u_{c t_{2}} M_{t_{2}}^{*} \frac{W_{t_{2}}}{A(1-\tau)}\right]}{E_{t_{1}}\left[u_{c t_{2}} M_{t_{2}}\right]}
\end{aligned}
$$

Next, consider firm entry decisions. Firms enter until profit exceeds the fixed cost in expectations, evaluated in terms of marginal utility. Consider entry of home firms into the foreign market:

$$
\begin{aligned}
& E_{t_{0}}\left[u_{c t_{2}} \pi_{H t_{2}}^{*}(i)\right]=0 \\
& E_{t_{0}}\left[u_{c t_{2}}\left\{\left(s_{t_{2}} p_{H_{t 1}}^{*}(i)-\frac{W_{t_{2}}}{A_{t_{2}}(1-\tau)}\right) C_{H_{t 2}}^{*}(i)-W_{t_{2}} F^{*}\right\}\right]=0
\end{aligned}
$$

Substituting in definitions of demands and prices:

$$
E_{t_{0}}\left[u_{c t_{2}}\left\{\left(s_{t_{2}} p_{H+1}^{*}(i)-\frac{W_{t_{2}}}{A_{t_{2}}(1-\tau)}\right) n_{H t_{0}}^{*-\gamma-\phi+\gamma \phi} \frac{1}{2}\left(P_{H t_{1}}^{*}(i) / P_{t_{1}}^{*}\right)^{-\phi} \frac{M_{t_{2}}^{*}}{P_{t_{1}}^{*}}\right\}\right]-E_{t_{0}}\left[u_{c t_{2}} W_{t_{2}}\right] F^{*}=0
$$

Solving for number of firms:

$$
\left.n_{H_{0}}^{*}=\left\{\frac{E_{t_{0}}\left[u_{c t_{2}} M_{t_{2}}\left(p_{H t_{1}}^{*}(i)\right)^{1-\phi} P_{t_{1}}^{*(\phi-1)}\right]-E_{t_{0}}\left[u_{c t_{2}} M_{t_{2}}^{*} \frac{W_{t_{2}}}{A_{t_{2}}(1-\tau)}\left(p_{H t_{1}}^{*}(i)\right)^{-\phi} P_{t_{1}}^{*(\phi-1)}\right]}{2 E_{t_{0}}\left[u_{c t_{2}} W_{t_{2}}\right] F^{*}}\right\}\right\}^{\frac{1}{\gamma+(1-\gamma) \phi}}
$$

Similarly for entry of home firms into the domestic market:

$$
n_{H t_{0}}=\left\{\frac{E_{t_{0}}\left[u_{c t_{2}} M_{t_{2}}\left(p_{H t_{1}}(i)\right)^{1-\phi} P_{t_{1}}^{(\phi-1)}\right]-E_{t_{0}}\left[u_{c t_{2}} M_{t_{2}} \frac{W_{t_{2}}}{A_{t_{2}}}\left(p_{H t_{1}}(i)\right)^{-\phi} P_{t_{1}}^{(\phi-1)}\right]}{2 E_{t_{0}}\left[u_{c t_{2}} W_{t_{2}}\right] F}\right\}^{\frac{1}{\gamma+(1-\gamma) \phi}}
$$




\subsection{Equilibrium Nominal Exchange Rate Determination}

The equilibrium nominal exchange rate can be derived explicitly, under the assumption of a fully symmetric structure. Foreign exchange market clearing requires that excess supply of the two currencies must be zero in equilibrium. Under the assumption of balanced trade, equate the value of imports to the value of export revenue:

$$
P_{\mathrm{Ft}_{1}} C_{\mathrm{Ft}_{2}}-S_{t_{2}} P_{\mathrm{Ht}_{1}}^{*} C_{\mathrm{Ht}_{2}}^{*}=0
$$

Assume full symmetry across countries, so $P_{F t_{1}}=P_{H t_{1}}^{*}$ and $P_{t_{1}}=P_{t_{1}}^{*}$. Substituting the demand function of traded goods, we can solve

$$
S_{t_{2}}=\frac{M_{t_{2}}}{M_{t_{2}}^{*}}
$$

The equilibrium nominal exchange rate is equal to the ratio of money supplies. Clearly, this is a very simple exchange rate equation, but it captures the relationship between nominal exchange rate and fundamentals directly.

In addition, it's assumed that the Home and Foreign money supplies, $M$ and $M^{*}$, are both log-normally distributed, which is defined by

$$
\log (M)=\bar{m}+\varepsilon
$$

where $\bar{m}$ is a constant and $\varepsilon$ is an i.i.d random variable with a normal distribution, $N\left(0, \sigma_{m}^{2}\right)$.

This implies,

$$
E_{t_{1}}\left(M_{t_{2}}\right)=\exp \left(\bar{m}+\frac{1}{2} \sigma_{m}^{2}\right)
$$

The distribution of $M$ and $M^{*}$ is jointly symmetric, with a correlation that equals 1 under a peg and a currency union, and a correlation that equals zero under pure float. This implies that 
$\bar{m}=\bar{m}^{*}$ and $\sigma_{m}^{2}=\sigma_{m}^{* 2}=\sigma^{2}$, thus the uncertainty of the nominal exchange rate under a pure float comes from the randomly distributed disturbance in the money supply, $\sigma^{2}$,

$$
E_{t_{1}}\left(s_{t_{2}}\right)=E_{t_{1}}\left(\frac{M_{t_{2}}}{M_{t_{2}}^{*}}\right)=\exp \left(\sigma^{2}\right)
$$

\subsection{Effects of Exchange Rate Regimes on Price Setting}

The firm price setting behavior in this model is identical to that developed in Bacchetta and van Wincoop (2000). Using equations (10) and (25) to substitute for the endogenous wage and exchange rate in the price-setting equations (19) and (20):

$$
\begin{aligned}
& p_{H t_{1}}(i)=\left(\frac{\mu}{\mu-1}\right) \frac{P_{t_{1}}}{A} \frac{E_{t_{1}}\left[u_{t_{t_{2}}} M_{t_{2}}\right]}{E_{t_{1}}\left[u_{c t_{2}} M_{t_{2}}\right]} \\
& p_{H t_{1}}^{*}(i)=\left(\frac{\mu}{\mu-1}\right) \frac{P_{t_{1}}}{A(1-\tau)} \frac{E_{t_{1}}\left[u_{t_{t_{2}}} M_{t_{2}}^{*}\right]}{E_{t_{1}}\left[u_{c t_{2}} M_{t_{2}}\right]}
\end{aligned}
$$

Consider first the case of a floating exchange rate, where the money supplies of the two countries move independently. Under the assumption of substitutability between consumption

and leisure, it must be that $E_{t_{1}}\left[u_{l_{2}} M_{t_{2}}\right]<E_{t_{1}}\left[u_{l_{t_{2}}} M_{t_{2}}^{*}\right]$. Intuitively, a shock raising home money supply will raise home consumption but not foreign consumption, because the cash in advance constraint for home money involves only home consumption. Because home consumption includes both home and foreign goods, this will lower both home and foreign labor. Given that consumption and leisure are substitutes, the rise in home consumption will help offset the rise in the marginal utility of leisure when it is due to a home money rise. This is not true for a rise in foreign money, which lowers home leisure but does not raise home consumption. As a result, the home marginal utility of leisure has a smaller covariance with 
home money than it does with foreign money, and $E_{t_{1}}\left[u_{l t_{2}} M_{t_{2}}\right]<E_{t_{1}}\left[u_{l_{t_{2}}} M_{t_{2}}^{*}\right]$. Another way to view this is that the rise in wage rate needed to clear the money market is higher for a foreign money shock than a home money shock, so that the expected costs of production rise more for a foreign money shock. The higher price represents a risk premium associated with sales abroad. This, along with the fact that exporters must pay the iceberg trade cost, ensures that export prices are higher than domestic goods prices. Of course, if we were to assume instead that consumption and leisure were not substitutes, this result would change. See the appendix of Bacchetta and van Wincoop (2000) for a proof of this point.

Next consider the case where exchange rates are fixed, which requires that home and foreign money supplies are perfectly correlated. This condition is true for both direct pegs and currency unions. Now a rise in money supply (home and foreign together) will always raise home consumption along with the fall in leisure. So $E_{t_{1}}\left[u_{l t_{2}} M_{t_{2}}\right]=E_{t_{1}}\left[u_{l t_{2}} M_{t_{2}}^{*}\right]$, and there is no risk premium raising export prices over domestic prices; export prices will be higher only due to iceberg trade costs.

Given that shocks are i.i.d. and prices are preset, then conditional on knowledge of the exchange rate regime, prices will not be time-varying. Let us indicate these constant prices with over-bars, and summarize the results above with the following statement:

$$
\frac{\bar{p}_{H, C U}^{*}(i)}{\bar{p}_{H, C U}(i)}=\frac{\bar{p}_{H, P e g}^{*}(i)}{\bar{p}_{H, P e g}(i)}<\frac{\bar{p}_{H, \text { float }}^{*}(i)}{\bar{p}_{H, \text { float }}(i)} .
$$

\subsection{Effects of Exchange Rate Regimes on Number of Firms}

We next study the implications of the entry conditions (22) and (23) under alternative exchange rate regimes. Consider first a currency union. In this case, it is known already in 
period $t_{0}$ that there will be no exchange rate movements in period $t_{2}$, so firms expect that prices set in period $t_{1}$ will correspond to the result derived above for a fixed exchange rate. Under this information set, the entry condition (22) then can be written:

$$
n_{H, C U, t_{0}}^{*}=\left\{\frac{1}{2}\left(\frac{1}{\mu}\right) \bar{P}_{C U}^{*(\phi-1)} E_{t_{0}}\left[u_{c t_{2}} M_{t_{2}}\right]\left(\bar{p}_{H, C U}^{*}(i)\right)^{1-\phi} /\left[E_{t_{0}}\left[u_{c t_{2}} W_{t_{2}}\right] F^{*}\right]\right\}^{\frac{1}{\gamma+(1-\gamma) \phi}}
$$

(See the appendix for the derivation.) The subscript $C U$ indicates a currency union, but for prices we continue to use the subscript fix, because this term will apply to all cases where exchange rates are fixed, including a direct peg. The exponent depends on the degree of love of variety, $\gamma$, as well as the aggregate elasticity of substitution between home and foreign goods, $\phi$. If we assume no love for variety ( $\gamma=1$ ), then the exponent takes the value of 1 and disappears. Under the calibration consistent with Dixit-Stiglitz preferences $\left(\gamma=\frac{\mu}{\mu-1}\right.$, where $\mu$ is the elasticity of substitution between varieties), this exponent takes the value $(\mu-1) /(\mu-\phi)$. The corresponding condition for the domestic number of firms is analogous. It turns out to be very convenient to express the two as a ratio, as several terms common across the two cancel under symmetry across countries (including some expectations difficult to deal with, $E_{t_{0}}\left[u_{c t_{2}} M_{t_{2}}\right]$ and $E_{t_{0}}\left[u_{c t_{2}} W_{t_{2}}\right]$ :

$$
\frac{n_{H, C U, t_{0}}^{*}}{n_{H, C U, t_{0}}}=\left(\frac{\bar{p}_{H, C U}^{*}(i)}{\bar{p}_{H, C U}(i)}\right)^{\frac{1-\phi}{\gamma(1-\phi)+\phi}}\left(\frac{F^{*}}{F}\right)^{\frac{1}{\gamma+(1-\gamma) \phi}}=\left(\frac{1}{1-\tau}\right)^{\frac{1-\phi}{\gamma(1-\phi)+\phi}}\left(\frac{F}{F^{*}}\right)^{\frac{1}{\gamma+(1-\gamma) \phi}}
$$

This expression can be viewed as the product of two terms, the first being a relative price term, and the second a relative fixed cost term. The exponent on the price term can take the value of $1-\phi$ for the case of no love for variety, or the value of $(\mu-1)(1-\phi) /(\mu-\phi)$ for the case of Dixit-Stiglitz preferences, both of which will be negative for values of $\phi>1$. In the case of a 
currency union, the price set by firms is the same in both markets, except for the iceberg cost, so entry in the export market is lower than domestic entry due only to the presence of iceberg and fixed trade costs.

Consider next the case of a float. As derived in the appendix,

$$
n_{, \text {float }, t_{0}}^{*}=\left\{\frac{1}{2}\left(\frac{1}{\mu}\right) \bar{P}_{\text {float }}^{*(\phi-1)} E_{t_{0}}\left[u_{c t_{2}} M_{t_{2}}\right]\left(\bar{p}_{H, f l o a t}^{*}(i)\right)^{1-\phi} /\left[E_{t_{0}}\left[u_{c t_{2}} W_{t_{2}}\right] F^{*}\right]\right\}^{\frac{1}{\gamma+(1-\gamma) \phi}}
$$

And taking a ratio to the analogous entry of home firms into the domestic market:

$$
\frac{n_{H, \text { float } t_{0}}^{*}}{n_{H, \text { float }, t_{0}}}=\left(\frac{\bar{p}_{H, \text { float }}^{*}(i)}{\bar{p}_{H, \text { float }}(i)}\right)^{\frac{1-\phi}{\gamma(1-\phi)+\phi}}\left(\frac{F^{*}}{F}\right)^{\frac{1}{\gamma+(1-\gamma) \phi}}
$$

As seen above, there is a large gap between export and domestic price setting under a float in this model $\frac{\bar{p}_{H, f l o a t}^{*}(i)}{\bar{p}_{H, f l o a t}(i)}>\frac{\bar{p}_{H, C U}^{*}(i)}{\bar{p}_{H, C U}(i)}=\frac{1}{1-\tau}$. This implies a float will discourage entry in the export market relative to domestic entry.

Finally, we consider the case of a direct peg. Because firms expect a peg adopted in period $t_{0}$ to collapse by period $t_{2}$, the expectation in period $t_{0}$ for prices in $t_{1}$ are the same prices as under a float. Hence the number of firms determined in period $t_{0}$ will be the same as under a float:

$$
n_{H, p e g, t_{0}}^{*}=\left\{\frac{1}{2}\left(\frac{1}{\mu}\right) \bar{P}_{f l o a t}^{*(\phi-1)} E_{t_{0}}\left[u_{c t_{2}} M_{t_{2}}\right]\left(\bar{p}_{H, \text { float }}^{*}(i)\right)^{1-\phi} /\left[E_{t_{0}}\left[u_{c t_{2}} W_{t_{2}}\right] F^{*}\right]\right\}^{\frac{1}{\gamma+(1-\gamma) \phi}}
$$

and $\quad \frac{n_{H, \text { peg } t_{0}}^{*}}{n_{H, \text { peg } t_{0}}}=\left\{\left(\frac{\bar{p}_{H, \text { float }}^{*}(i)}{\bar{p}_{H, \text { float }}(i)}\right)^{1-\phi} / \frac{F^{*}}{F}\right\}^{\frac{1}{\gamma+(1-\gamma) \phi}}$

As a result we can conclude the following relationship of entry among regimes under our 
assumptions: $\frac{n_{H, C U, t_{0}}^{*}}{n_{H, C U, t_{0}}}>\frac{n_{H, p e g, t_{0}}^{*}}{n_{H, p e g, t_{0}}}=\frac{n_{H, \text { float }, t_{0}}^{*}}{n_{H, \text { float }, t_{0}}}$ for $\phi>1$ and $\gamma \leq \phi /(\phi-1)$.

\subsection{Implications for Export Share, and the Extensive and Intensive Margins.}

Finally, we are ready to decompose the effects of exchange rate regimes into extensive and intensive margins. As this is a two-country model, whereas the data set is from a multicountry setting, we must work a bit to construct theoretical measures of the trade margins as close as possible to those in the empirical work. The extensive margin in the empirical section scales the number of products traded between two countries by the trade in products with all countries; in our two-country world, we will scale the number of firms traded by the number of all firms that sell domestically. This scaling, similar in spirit, allows us to use the relative extensive margin measure derived in the section above due to symmetry:

$$
E M \equiv \frac{n_{H t_{0}}^{*}}{n_{F t_{0}}^{*}}=\frac{n_{H t_{0}}^{*}}{n_{H t_{0}}}
$$

In keeping with this measure of the extensive margin, we will measure the export share as the ratio of the value of home exports to the foreign market divided by the value of domestic sales in the foreign market. Under symmetry:

$$
\text { EXShare }=\frac{P_{H t_{1}}^{*} C_{H t_{2}}^{*}}{P_{F t_{1}}^{*} C_{F t_{2}}^{*}}=\frac{P_{H t_{1}}^{*} 0.5\left(\frac{P_{H t_{1}}^{*}}{P_{t_{1}}^{*}}\right)^{-\phi} C_{t_{2}}^{*}}{P_{F t_{1}}^{*} 0.5\left(\frac{P_{F t_{1}}^{*}}{P_{t_{1}}^{*}}\right)^{-\phi} C_{t_{2}}^{*}}=\left(\frac{P_{H t_{1}}^{*}}{P_{F t_{1}}^{*}}\right)^{1-\phi}=\left(\frac{P_{H t_{1}}^{*}}{P_{H t_{1}}}\right)^{1-\phi} .
$$

This implies the appropriate measure of the intensive margin, sales per firm, also be represented relative to domestic market:

$$
I M \equiv\left(\frac{P_{H_{1}}^{*} C_{H t_{2}}^{*}}{n_{H t_{0}}^{*}}\right) /\left(\frac{P_{F t_{1}}^{*} C_{F t_{2}}^{*}}{n_{F t_{0}}^{*}}\right)=\left(\frac{P_{H t_{1}}^{*}}{P_{F t_{1}}^{*}}\right)^{1-\phi} /\left(\frac{n_{H t_{0}}^{*}}{n_{F t_{0}}^{*}}\right)=\left(\frac{P_{H t_{1}}^{*}}{P_{H t_{1}}}\right)^{1-\phi} /\left(\frac{n_{H_{0}}^{*}}{n_{H t_{0}}}\right) .
$$


First, we wish to show that the export share rises for a peg and currency union compared to a float, but that the effect is larger for a currency union. First for a currency union:

$$
\begin{aligned}
& \frac{\text { EXShare }_{C U}}{\text { EXShare }_{\text {float }}}=\left(\frac{P_{H, C U, t_{1}}^{*} / P_{H, C U, t_{1}}}{P_{H, \text { float }, t_{1}}^{*} / P_{H, \text { flaot }, t_{1}}}\right)^{1-\phi}=\left(\frac{n_{H, C U, t_{1}}^{*} / n_{H, C U, t_{1}}}{n_{H, \text { float }, t_{1}}^{*} / n_{H, \text { float }, t_{1}}}\right)^{(1-\phi)(1-\gamma)}\left(\frac{p_{H, C U, t_{1}}^{*}(i) / p_{H, C U, t_{1}}(i)}{p_{H, \text { float }, t_{1}}^{*}(i) / p_{H, \text { float }, t_{1}}(i)}\right)^{1-\phi} \\
& =\left(\frac{n_{H, C U, t_{1}}^{*} / n_{H, C U, t_{1}}}{n_{H, \text { float } t_{1}}^{*} / n_{H, \text { float }, t_{1}}}\right)^{(1-\phi)(1-\gamma)}\left(\frac{\left(\frac{\mu}{\mu-1}\right) \frac{P_{C U, t_{1}}}{A(1-\tau)} \frac{E_{t_{1}}\left[u_{l t_{2}} M_{t_{2}}^{*} \mid C U\right]}{E_{t_{1}}\left[u_{c t_{2}} M_{t_{2}} \mid C U\right]} /\left(\frac{\mu}{\mu-1}\right) \frac{P_{C U, t_{1}}}{A} \frac{E_{t_{1}}\left[u_{l t_{2}} M_{t_{2}} \mid C U\right]}{E_{t_{1}}\left[u_{c t_{2}} M_{t_{2}} \mid C U\right]}}{\left(\frac{\mu}{\mu-1}\right) \frac{P_{\text {float } t_{1}}}{A(1-\tau)} \frac{E_{t_{1}}\left[u_{l t_{2}} M_{t_{2}}^{*} \mid \text { float }\right]}{E_{t_{1}}\left[u_{c t_{2}} M_{t_{2}} \mid \text { float }\right]} /\left(\frac{\mu}{\mu-1}\right) \frac{P_{\text {float }, t_{1}}}{A} \frac{E_{t_{1}}\left[u_{l t_{2}} M_{t_{2}} \mid \text { float }\right]}{E_{t_{1}}\left[u_{c t_{2}} M_{t_{2}} \mid \text { float }\right]}}\right)^{1-\phi} \\
& =\left(\frac{E M_{C U}}{E M_{\text {float }}}\right)^{(\phi-1)(\gamma-1)}\left(\frac{E_{t_{1}}\left[u_{l t_{2}} M_{t_{2}}^{*} \mid \text { float }\right]}{E_{t_{1}}\left[u_{l t_{2}} M_{t_{2}} \mid \text { float }\right]}\right)^{(\phi-1)}
\end{aligned}
$$

We know from the discussion of price setting that the second term is greater than unity, reflecting the fact that under a float export prices are higher than domestic prices due to risk, while under a currency union this is not true. Lower export prices will raise export revenues provided demand is elastic. And we know from the discussion of extensive margins that the first term is greater than unity, provided there is love for variety. So we have two reasons why trade is higher under a currency union: lower export prices relative to domestic prices, and love of variety.

For a direct peg, firm-level price setting is the same as a currency union, while the number of firms is the same as under a float:

$$
\begin{aligned}
& \frac{\text { EXShare }_{\text {peg }}}{\text { EXShare }_{\text {float }}}=\left(\frac{n_{H, \text { float } t_{1}}^{*} / n_{H, \text { float }, t_{1}}}{n_{H, \text { float }, t_{1}}^{*} / n_{H, \text { float }, t_{1}}}\right)^{(1-\phi)(1-\gamma)}\left(\frac{p_{H, \text { peg }, t_{1}}^{*}(i) / p_{H, \text { peg }, t_{1}}(i)}{p_{H, \text { float }, t_{1}}^{*}(i) / p_{H, \text { float }, t_{1}}(i)}\right)^{1-\phi} \\
& =\left(\frac{E_{t_{1}}\left[u_{l_{t_{2}}} M_{t_{2}}^{*} \mid \text { float }\right]}{E_{t_{1}}\left[u_{l_{t_{2}}} M_{t_{2}} \mid \text { float }\right]}\right)^{(\phi-1)}
\end{aligned}
$$

So we can conclude: 


$$
\frac{\text { EXShare }_{C U}}{\text { EXShare }_{\text {float }}}=\left(\frac{E M_{C U}}{E M_{\text {float }}}\right)^{(\phi-1)(\gamma-1)} \frac{\text { EXShare }_{\text {peg }}}{\text { EXShare }_{\text {float }}}
$$

The rise in trade under a currency union is greater than under a direct peg, by a factor proportional to the rise in the extensive margin, with the proportionality depending on love for variety.

Next, decompose the rise in export share into extensive and intensive margins. Using conditions (33) and (35) with (41):

$$
\begin{aligned}
& \frac{\text { EXShare }_{C U}}{\text { EXShare }_{\text {float }}}=\left(\frac{E M_{C U}}{E M_{\text {float }}}\right)^{(1-\phi)(1-\gamma)}\left(\frac{p_{H, C U, t_{1}}^{*}(i) / p_{H, C U, t_{1}}(i)}{p_{H, \text { float }, t_{1}}^{*}(i) / p_{H, \text { float }, t_{1}}(i)}\right)^{1-\phi}=\left(\frac{E M_{C U}}{E M_{\text {float }}}\right)^{(1-\phi)(1-\gamma)} \frac{\left(E M_{C U}\right)^{\gamma+(1-\gamma) \phi} \frac{F}{F^{*}}}{\left(E M_{\text {float }}\right)^{\gamma+(1-\gamma) \phi} \frac{F}{F^{*}}} \\
& =\frac{E M_{C U}}{E M_{\text {float }}}
\end{aligned}
$$

So the percentage rise in export share from float to currency union is equal to the percentage rise in the extensive margin. That is, $100 \%$ of the rise in trade is attributable to the extensive margin, and none due to the intensive margin. This result is consistent with our empirical finding. Nonetheless, it is somewhat surprising. Given that firms hedge against exchange rate risk in price setting with a risk premium raising prices, one might expect this would also help hedge against the effects of exchange rate risk on the entry decision. But this is not the case.

The story is quite different for a direct peg. Given that the extensive margin is unchanged from a float to a direct peg, by definition, the rise in export share is all due to the intensive margin. This again corresponds to our empirical finding.

\section{Conclusion}

This paper finds that currency unions and direct pegs raise trade volume through distinct 
channels. Panel data analysis of the period 1973-2000 indicates that currency unions have raised trade largely at the extensive margin, the entry of new firms or products. In contrast, direct pegs have raised trade almost entirely at the intensive margin, increased trade in existing products. A theoretical model is developed to understand this finding, featuring price stickiness and firm entry under uncertainty. Because both regimes provide exchange rate stability over the horizon of price setting, they lead to lower export prices and greater demand for exports. But because currency unions are more credible at a longer horizon, they encourage firms to make the longer-term investment needed to enter a new market.

Our model does not rule out the possibility that adopting a currency union could additionally expand the extensive margin by affecting fixed costs. These could involve deterministic effects, such as the elimination of currency conversion or other transactions costs, which would lower the fixed cost $F^{*}$. In addition, the model could be extended to consider fixed costs that themselves are affected by exchange rate risk, such as entry into foreign markets committing to fixed expenditures in foreign labor units in future periods. The fixed costs term, $F^{*}$, then becomes stochastic, and its expected value could fall under exchange rate stabilization, encouraging entry.

This model abstracted from firm heterogeneity, in order to get a closed form solution under uncertainty for the number of firms. If firms were heterogeneous in terms of their productivity levels, this likely would work in the opposite direction of explaining the higher rise in exports under a currency union compared to a direct peg. Since a currency union implies a larger extensive margin effect, the new entrants would systematically have lower productivity than incumbent firms. This would lower the average productivity of market participants and raise the export price index, which would limit the increase in aggregate trade volume. 


\section{References}

Anderson, James E. and Eric van Wincoop, 2003. Gravity with Gravitas: A Solution to the Border Puzzle. American Economic Review 93:1, 170-92.

Anderson, James E. and Eric van Wincoop, 2004. Trade Costs. Journal of Economic Literature 42:3, 691-741.

Bacchetta, Philippe and Eric van Wincoop, 2000. Does Exchange-Rate Stability Increase Trade and Welfare? American Economic Review 90, 1093-1109.

Baldwin, Richard, 2006. The euro’s trade effects, European Central Bank Working Paper No 594.

Baldwin, Richard and Virginia Di Nino 2006. Euros and zeros: the common currency effect on trade in new goods, HEI Working Paper No. 21/2006.

Baldwin, Richard, Frauke Skudelny and Daria Taglioni, 2005. Trade effects of the euro: evidence from sectoral data. European Central Bank Working Paper No. 446.

Benassy, J.P., 1996. Taste for variety and optimum production patterns in monopolistic competition. Economics Letters 52, 41-47

Bergin, Paul and Reuven Glick, 2007, Productivity, Tradability, and International Economic Integration, Journal of International Economics 73 (1), 128-151.

Bergin, P.R., Glick, R., Taylor, A.M., 2006. Productivity, tradability, and the long-run price puzzle, Journal of Monetary Economics 53, 2041--2066.

Bernard, Andrew, Steven Redding, and Peter Schott, 2006. Multi-product firms and trade Liberalization, NBER Working Paper No. 12782.

Cushman, David O., 1983. The effects of real exchange rate risk on international trade, Journal of International Economics 15, 45-63.

Feenstra, Robert, 1994. New Product Varieties and the Measurement of International Prices,' American Economic Review 84, 157-177.

Feenstra, Robert, Lipsey, Deng, Ma, Mo, 2005.World Trade Flows: 1962-2000, NBER Working Paper 11040.

Frankel, Jeffrey and Andrew K. Rose, 2002. An estimate of the effect of common currencies on trade and income, Quarterly Journal of Economics 117, 437-466.

Ghironi, Fabio, and Marc Melitz, 2005. International Trade and Macroeconomic Dynamics with Heterogeneous Firms, The Quarterly Journal of Economics 120, 865-915. 
Glick Reuven and Andrew Rose, 2002. Does a currency union affect trade? The time series evidence, European Economic Review 46, 1125-1151.

Hummels, David and Peter J. Klenow, 2005. The Variety and Quality of a Nation's Trade, American Economic Review, June, 704-723.

Kehoe, Timothy J., and Kim J. Ruhl, 2002. How Important is the New Goods Margin in International Trade? working paper, University of Minnesota.

Klein, Michael W., 1990. Sectoral effects of exchange rate volatility on United States exports, Journal of International Money and Finance 9, 299-308.

Klein, Michael W. and Jay C. Shambaugh, 2006. Fixed exchange rates and trade, Journal of International Economics 70, 359-383.

Klein, Michael W. and Jay C. Shambaugh, 2007. The dynamics of exchange rate regimes: fixes, floats, and flips, mimeo.

Kumhoff, Michael, Douglas Laxton, and Kanda Naknoi, 2007. Does the exchange rate belong in monetary policy rules? New answers from a DSGE with endogenous tradability and trade frictions, mimeo Purdue University.

Naknoi, Kanda, 2007. Real exchange rate fluctuations, endogenous tradability and exchange rate regimes, forthcoming in the Journal of Monetary Economics.

Nitsch, Volker. 2002, Honey, I shrunk the currency union effect on trade, World economy 4, 457-474.

Persson, T., 2001. Currency unions and trade: how large is the treatment effect? Economic Policy 30, 435-448.

Rose, Andrew, 2000. One money, one market: the effect of common currencies on trade. Economic Policy: a European Forum 30, 7-33.

Rose, Andrew, 2004. Do We Really Know That the WTO Increases Trade? American Economic Review 94:1, 98-114

Rose, Andrew K. and Eric van Wincoop, 2001. National money as a barrier to international trade: The real case for currency union. American Economic Review 91, 386-390. 


\section{Appendix}

\section{A1. Derivation of optimal price setting for exports:}

Rewrite profits in equation (18) in the text.

$$
\begin{aligned}
& \pi_{H}^{*}(i)=\left(s_{t_{2}} p_{H t 1}^{*}(i)-\frac{W_{t_{2}}}{A(1-\tau)}\right) c_{H t 2}^{*}(i)-f^{*} \\
& \pi_{H}^{*}(i)=\left(s_{t_{2}} p_{H t 1}^{*}(i)-\frac{W_{t_{2}}}{A(1-\tau)}\right)\left(P_{H_{t_{1}}}^{*}(i) / P_{H_{t_{1}}}^{*}\right)^{-\mu} n_{H_{t_{0}}}^{* \mu(\gamma-1)-\gamma} c_{H t 2}^{*}-f^{*} \\
& \pi_{H}^{*}(i)=\left(s_{t_{2}} p_{H t 1}^{*}(i)-\frac{W_{t_{2}}}{A(1-\tau)}\right)\left(P_{H_{t_{1}}}^{*}(i) / P_{H_{t_{1}}}^{*}\right)^{-\mu} n_{H_{t_{0}}}^{* \mu(\gamma-1)-\gamma} \frac{1}{2}\left(P_{H_{t_{1}}}^{*} / P_{t_{1}}^{*}\right)^{-\phi} c^{*} t_{t_{2}}-f^{*}
\end{aligned}
$$

The first order condition for the optimization problem is:

$$
E\left[u_{c} \frac{M^{*}}{P^{*}} \frac{1}{2} n_{H t_{0}}^{* \mu(\gamma-1)-\gamma}\left(\frac{p_{H}^{*}}{P^{*}}\right)^{-\phi}\left\{\left(s p_{H}^{*}(i)-\frac{W}{A(1-\tau)}\right)(-\mu)\left(\frac{p_{H}^{*}(i)}{p_{H}^{*}}\right)^{-\mu} \frac{1}{p_{H}^{*}(i)}+\left(\frac{p_{H}^{*}(i)}{p_{H}^{*}}\right)^{-\mu} s\right\}\right]=0
$$

Impose symmetry over varieties of home firms:

$$
E\left[u_{c} \frac{M^{*}}{P^{*}} \frac{1}{2} n_{H t_{0}}^{* \mu(\gamma-1)-\gamma}\left(\frac{p_{H}^{*}}{P^{*}}\right)^{-\phi}\left\{\left(s p_{H}^{*}-\frac{W}{A(1-\tau)}\right)(-\mu) \frac{1}{p_{H}^{*}}+s\right\}\right]=0
$$

Solve for pre-determined price:

$$
\begin{aligned}
& E\left[u_{c} \frac{M^{*}}{P^{*}} \frac{1}{2} n_{H t_{0}}^{* \mu(\gamma-1)-\gamma}\left\{\left(s-\frac{1}{p_{H}^{*}} \frac{W}{A(1-\tau)}\right)(-\mu)+s\right\}\right]=0
\end{aligned}
$$

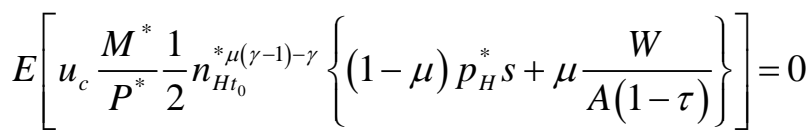

$$
\begin{aligned}
& p_{H}^{*}=\frac{E\left[u_{c} \frac{M^{*}}{P^{*}} \frac{1}{2} n_{H t_{0}}^{* \mu(\gamma-1)-\gamma}\left\{\mu \frac{W}{A(1-\tau)}\right\}\right]}{E\left[u_{c} \frac{M^{*}}{P^{*}} \frac{1}{2} n_{H t_{0}}^{* \mu(\gamma-1)-\gamma}\{(\mu-1) s\}\right]} \\
& p_{H}^{*}=\left(\frac{\mu}{\mu-1}\right) \frac{E\left[u_{c} M^{*} \frac{W}{A(1-\tau)}\right]}{E\left[u_{c} M^{*} s\right]}=\left(\frac{\mu}{\mu-1}\right) \frac{E\left[u_{c} M^{*} \frac{W}{A(1-\tau)}\right]}{E\left[u_{c} M\right]}
\end{aligned}
$$

\section{A2. Derivation of number of firms under a currency union:}

Since price setting is known from $t_{0}$ already, conditions (22) can be written: 


$$
n_{H, C U, t_{0}}^{*}=\left\{\frac{\frac{1}{2} \bar{P}_{C U}^{*(\phi-1)}\left[E_{t_{0}}\left[u_{c t_{2}} M_{t_{2}}\right]\left(\bar{p}_{H, C U}^{*}(i)\right)^{1-\phi}-E_{t_{0}}\left[u_{c t_{2}} M_{t_{2}}^{*} \frac{W_{t_{2}}}{A_{t_{2}}(1-\tau)}\right]\left(\bar{p}_{H, C U}^{*}(i)\right)^{-\phi}\right]}{E_{t_{2}}\left[u_{c t_{2}} W_{t_{2}}\right] F^{*}}\right\}^{\frac{1}{\gamma+(1-\gamma) \phi}}
$$

Now, we need to study the expectation of price setting. Taking expectations of condition (20):

Iterate expectations:

$$
E_{t_{1}}\left[u_{c t_{2}} M_{t_{2}}^{*} \frac{W_{t_{2}}}{A_{t_{2}}(1-\tau)}\right]=\left(\frac{\mu-1}{\mu}\right) \bar{p}_{H, C U}^{*}(i) E_{t_{1}}\left[u_{c t_{2}} M_{t_{2}}\right]
$$

$$
\begin{aligned}
& E_{t_{0}}\left[E_{t_{1}}\left[u_{c t_{2}} M_{t_{2}}^{*} \frac{W_{t_{2}}}{A_{t_{2}}(1-\tau)}\right]\right]=E_{t_{0}}\left[\left(\frac{\mu-1}{\mu}\right) \vec{p}_{H, C U}^{*}(i) E_{t_{1}}\left[u_{c t_{2}} M_{t_{2}}\right]\right] \\
& E_{t_{0}}\left[u_{c t_{2}} M_{t_{2}}^{*} \frac{W_{t_{2}}}{A_{t_{2}}(1-\tau)}\right]=\left(\frac{\mu-1}{\mu}\right) \vec{p}_{H, C U}^{*}(i) E_{t_{0}}\left[u_{c t_{2}} M_{t_{2}}\right]
\end{aligned}
$$

Substitute in:

$$
\begin{aligned}
& n_{H, C U, t_{0}}^{*}=\left\{\frac{\frac{1}{2} \bar{P}_{C U}^{*(\phi-1)}\left[E_{t_{0}}\left[u_{c t_{2}} M_{t_{2}}\right]\left(\bar{p}_{H, C U}^{*}(i)\right)^{1-\phi}-\left(\frac{\mu-1}{\mu}\right) \bar{p}_{H, C U}^{*} E_{t_{0}}\left[u_{c t_{2}} M_{t_{2}}\right]\left(\bar{p}_{H, C U}^{*}(i)\right)^{-\phi}\right]}{E_{t_{2}}\left[u_{c t_{2}} W_{t_{2}}\right] F^{*}}\right\}^{\frac{1}{\gamma+(1-\gamma) \phi}} \\
& n_{H, C U, t_{0}}^{*}=\left\{\frac{\frac{1}{2} \bar{P}_{C U}^{*(\phi-1)}\left[E_{t_{0}}\left[u_{c t_{2}} M_{t_{2}}\right]\left(\bar{p}_{H, C U}^{*}(i)\right)^{1-\phi}-\left(\frac{\mu-1}{\mu}\right) E_{t_{0}}\left[u_{c t_{2}} M_{t_{2}}\right]\left(\bar{p}_{H, C U}^{*}(i)\right)^{1-\phi}\right]}{E_{t_{2}}\left[u_{c t_{2}} W_{t_{2}}\right] F^{*}}\right\} \\
& n_{H, C U, t_{0}}^{*}=\left\{\frac{1}{2+(1-\gamma) \phi}\right. \\
& \left.\frac{1}{\mu}\left(\frac{1}{\mu}\right) \bar{P}_{C U}^{*(\phi-1)} E_{t_{0}}\left[u_{c t_{2}} M_{t_{2}}\right]\left(\bar{p}_{H, C U}^{*}(i)\right)^{1-\phi} /\left[E_{t_{2}}\left[u_{c t_{2}} W_{t_{2}}\right] F^{*}\right]\right\}^{\frac{1}{\gamma+(1-\gamma) \phi}}
\end{aligned}
$$

Which is equation (32) in the text.

Analogously for the number of home firms selling domestically:

$$
n_{H, C U, t_{0}}=\left\{\frac{1}{2}\left(\frac{1}{\mu}\right) \bar{P}_{C U}^{(\phi-1)} E_{t_{0}}\left[u_{c t_{2}} M_{t_{2}}\right]\left(\bar{p}_{H, C U}(i)\right)^{1-\phi} /\left[E_{t_{2}}\left[u_{c t_{2}} W_{t_{2}}\right] F\right]\right\}^{\frac{1}{\gamma+(1-\gamma) \phi}}
$$

\section{A3. Derivation of number of firms under a float:}

Start again with equation (22), but under the information set that you expect a float to be reasserted by the time sales begin in period $t_{2}$ : 


$$
n_{H, \text { float } t_{0}}^{*}=\left\{\frac{\frac{1}{2} \bar{P}_{\text {float }}^{*(\phi-1)}\left[E_{t_{0}}\left[u_{c t_{2}} M_{t_{2}}\right]\left(\bar{p}_{H, \text { float }}^{*}(i)\right)^{1-\phi}-E_{t_{0}}\left[u_{c t_{2}} M_{t_{2}}^{*} \frac{W_{t_{2}}}{A_{t_{2}}(1-\tau)}\right]\left(\bar{p}_{H, \text { float }}^{*}(i)\right)^{-\phi}\right]}{E_{t_{2}}\left[u_{c t_{2}} W_{t_{2}}\right] F^{*}}\right\}
$$

Now, we need to study the expectation of price setting. Taking expectations of condition (20):

$$
E_{t_{1}}\left[u_{c t_{2}} M_{t_{2}}^{*} \frac{W_{t_{2}}}{A_{t_{2}}(1-\tau)}\right]=\left(\frac{\mu-1}{\mu}\right) \bar{p}_{H, \text { float }}^{*}(i) E_{t_{1}}\left[u_{c t_{2}} M_{t_{2}}\right]
$$

Iterate expectations:

$$
\begin{aligned}
& E_{t_{0}}\left[E_{t_{1}}\left[u_{c t_{2}} M_{t_{2}}^{*} \frac{W_{t_{2}}}{A_{t_{2}}(1-\tau)}\right]\right]=E_{t_{0}}\left[\left(\frac{\mu-1}{\mu}\right) \bar{p}_{H, \text { float }}^{*}(i) E_{t_{1}}\left[u_{c t_{2}} M_{t_{2}}\right]\right] \\
& E_{t_{0}}\left[u_{c t_{2}} M_{t_{2}}^{*} \frac{W_{t_{2}}}{A_{t_{2}}(1-\tau)}\right]=\left(\frac{\mu-1}{\mu}\right) \bar{p}_{H, \text { float }}^{*}(i) E_{t_{0}}\left[u_{c t_{2}} M_{t_{2}}\right]
\end{aligned}
$$

Substitute in:

$$
\begin{aligned}
& n_{H, \text { float } t_{0}}^{*}=\left\{\frac{\frac{1}{2} \bar{P}_{\text {float }}^{*(\phi-1)}\left[E_{t_{0}}\left[u_{c t_{2}} M_{t_{2}}\right]\left(\bar{p}_{H, \text { float }}^{*}(i)\right)^{1-\phi}-\left(\frac{\mu-1}{\mu}\right) \bar{p}_{H, \text { float }}^{*} E_{t_{0}}\left[u_{c t_{2}} M_{t_{2}}\right]\left(\bar{p}_{H, \text { float }}^{*}(i)\right)^{-\phi}\right]}{E_{t_{2}}\left[u_{c t_{2}} W_{t_{2}}\right] F^{*}}\right\} \\
& n_{H, \text { float }, t_{0}}^{*}=\left\{\frac{\frac{1}{2} \bar{P}_{\text {float }}^{*(\phi-1)}\left[E_{t_{0}}\left[u_{c t_{2}} M_{t_{2}}\right]\left(\bar{p}_{H, \text { float }}^{*}(i)\right)^{\frac{1}{\gamma+(1-\gamma) \phi}}-\left(\frac{\mu-1}{\mu}\right) E_{t_{0}}\left[u_{c t_{2}} M_{t_{2}}\right]\left(\bar{p}_{H, \text { float }}^{*}(i)\right)^{1-\phi}\right]}{E_{t_{2}}\left[u_{c t_{2}} W_{t_{2}}\right] F^{*}}\right\} \\
& n_{H, \text { float }, t_{0}}^{*}=\left\{\frac{1}{2}\left(\frac{1}{\mu}\right) \bar{P}_{\text {float }}^{*(\phi-1)} E_{t_{0}}\left[u_{c t_{2}} M_{t_{2}}\right]\left(\bar{p}_{H, \text { float }}^{*}(i)\right)^{1-\phi} /\left[E_{t_{2}}\left[u_{c t_{2}} W_{t_{2}}\right] F^{*}\right]\right\}^{\frac{1}{\gamma+(1-\gamma) \phi}}
\end{aligned}
$$

Which is equation (34) in the text.

Analogously for the number of home firms selling domestically:

$$
n_{H, \text { float } t_{0}}=\left\{\frac{1}{2}\left(\frac{1}{\mu}\right) \bar{P}_{\text {float }}^{(\phi-1)} E_{t_{0}}\left[u_{c t_{2}} M_{t_{2}}\right]\left(\bar{p}_{H, \text { float }}(i)\right)^{1-\phi} /\left[E_{t_{2}}\left[u_{c t_{2}} W_{t_{2}}\right] F\right]\right\}^{\frac{1}{\gamma+(1-\gamma) \phi}}
$$


Table 1. Panel regression with country fixed effects from 1973-2000

\begin{tabular}{|c|c|c|c|}
\hline \multicolumn{4}{|c|}{ bilateral exports of 148 countries from 1973-2000 } \\
\hline & \multicolumn{2}{|c|}{ Panel Regression with Country Fixed effects } \\
\hline $\begin{array}{c}\text { Dependent } \\
\text { Variable }\end{array}$ & $\begin{array}{c}\text { logarithm of the } \\
\text { extensive margin }\end{array}$ & $\begin{array}{c}\text { logarithm of the } \\
\text { intensive margin }\end{array}$ & $\begin{array}{c}\text { logarithm of the } \\
\text { export share }\end{array}$ \\
\hline Currency Union & $\begin{array}{c}0.913^{* *} \\
(0.165)\end{array}$ & $\begin{array}{c}-0.117 \\
(0.107)\end{array}$ & $\begin{array}{c}0.796^{* *} \\
(0.181)\end{array}$ \\
\hline Direct Peg & 0.006 & $0.225^{* *}$ & $0.230^{* *}$ \\
& $(0.100)$ & $(0.060)$ & $(0.088)$ \\
\hline Indirect Peg & $-0.037^{*}$ & $-0.048^{*}$ & $-0.084^{*}$ \\
$(0.029)$ & $(0.023)$ & $(0.034)$ \\
\hline Exchange Rate & $-0.060^{*}$ & $0.045^{*}$ & -0.015 \\
Volatility & $(0.029)$ & $(0.023)$ & $(0.035)$ \\
\hline ln relative real & $0.873^{* *}$ & $0.319^{* *}$ & $1.192^{* *}$ \\
GDPpc & $(0.031)$ & $(0.026)$ & $0.036)$ \\
\hline ln relative & $0.640^{* *}$ & $0.261^{* *}$ & $0.901^{* *}$ \\
Population & $(0.033)$ & $-0.027)$ & $(0.036)$ \\
\hline ln Distance & $-0.875^{* *}$ & $(0.013)$ & $-1.156^{* *}$ \\
\hline Common & $(0.016)$ & -0.005 & $0.019)$ \\
\hline Language & $0.338^{* *}$ & $(0.023)$ & $(0.036)$ \\
\hline Border & $-0.029)$ & $0.240^{* *}$ & $0.183^{*}$ \\
& $(0.058$ & $0.056)$ & $(0.088)$ \\
\hline Free Trade & $-0.413^{* *}$ & $0.528^{* *}$ & 0.115 \\
Agreement & $(0.091)$ & $(0.045)$ & $(0.079)$ \\
\hline Currently in & 0.023 & $0.638^{* *}$ & $0.661^{* *}$ \\
Colonial & $(0.234)$ & $(0.170)$ & $(0.173)$ \\
relationship & $0.672^{* *}$ & $0.456^{* *}$ & $1.128^{* *}$ \\
\hline Ever in & $(0.063)$ & $(0.048)$ & $(0.076)$ \\
Colonial & 172544 & 172544 & 172544 \\
relationship & 0.64 & 0.57 & 0.74 \\
\hline Observations & & & \\
\hline R-sq & & & \\
\hline
\end{tabular}

** significant at $1 \%$; *significant at $5 \%$ 
Table 2. Panel regressions with country year fixed effects from 1973-2000

\begin{tabular}{|c|c|c|c|}
\hline \multicolumn{4}{|c|}{ bilateral exports of 148 countries from $1973-2000$} \\
\hline & \multicolumn{3}{|c|}{ Panel Regression with Country Year Fixed effects } \\
\hline $\begin{array}{c}\text { Dependent } \\
\text { Variable }\end{array}$ & $\begin{array}{l}\text { logarithm of the } \\
\text { extensive margin }\end{array}$ & $\begin{array}{l}\text { logarithm of the } \\
\text { intensive margin }\end{array}$ & $\begin{array}{l}\text { logarithm of the } \\
\text { export share }\end{array}$ \\
\hline Currency Union & $\begin{array}{l}0.612 * * \\
(0.162)\end{array}$ & $\begin{array}{l}-0.002 \\
(0.120)\end{array}$ & $\begin{array}{l}0.610^{* *} \\
(0.187) \\
\end{array}$ \\
\hline Direct Peg & $\begin{array}{l}-0.003 \\
(0.082)\end{array}$ & $\begin{array}{l}0.223^{* *} \\
(0.061)\end{array}$ & $\begin{array}{l}0.221^{*} \\
(0.092)\end{array}$ \\
\hline Indirect Peg & $\begin{array}{l}-0.078^{*} \\
(0.0331)\end{array}$ & $\begin{array}{l}-0.042 \\
(0.027)\end{array}$ & $\begin{array}{c}-0.121^{* *} \\
(0.040)\end{array}$ \\
\hline $\begin{array}{l}\text { Exchange Rate } \\
\text { Volatility }\end{array}$ & $\begin{array}{l}-0.142 \\
(0.399)\end{array}$ & $\begin{array}{l}-0.402 \\
(0.305)\end{array}$ & $\begin{array}{l}-0.543 \\
(0.440)\end{array}$ \\
\hline $\begin{array}{l}\text { In relative real } \\
\text { GDPpc }\end{array}$ & $\begin{array}{c}0.413 \\
(0.296)\end{array}$ & $\begin{array}{l}0.492 * \\
(0.211)\end{array}$ & $\begin{array}{l}0.905^{* *} \\
(0.211)\end{array}$ \\
\hline $\begin{array}{l}\text { In relative } \\
\text { Population }\end{array}$ & $\begin{array}{l}0.392 * * \\
(0.155)\end{array}$ & $\begin{array}{c}0.051 \\
(0.104)\end{array}$ & $\begin{array}{l}0.444^{* *} \\
(0.104)\end{array}$ \\
\hline ln Distance & $\begin{array}{c}-0.877^{* *} \\
(0.017) \\
\end{array}$ & $\begin{array}{c}-0.280 * * \\
(0.013) \\
\end{array}$ & $\begin{array}{c}-1.156^{* *} \\
(0.019) \\
\end{array}$ \\
\hline $\begin{array}{l}\text { Common } \\
\text { Language }\end{array}$ & $\begin{array}{c}0.344^{* *} \\
(0.030)\end{array}$ & $\begin{array}{l}-0.005 \\
(0.023)\end{array}$ & $\begin{array}{l}0.339 * * \\
(0.036)\end{array}$ \\
\hline Border & $\begin{array}{l}-0.102 \\
(0.084)\end{array}$ & $\begin{array}{l}0.273^{* *} \\
(0.056) \\
\end{array}$ & $\begin{array}{l}0.171^{*} \\
(0.088)\end{array}$ \\
\hline $\begin{array}{l}\text { Free Trade } \\
\text { Agreement }\end{array}$ & $\begin{array}{c}-0.589 * * \\
(0.090)\end{array}$ & $\begin{array}{l}0.600 * * \\
(0.048)\end{array}$ & $\begin{array}{c}0.011 \\
(0.080)\end{array}$ \\
\hline $\begin{array}{l}\text { Currently in } \\
\text { Colonial } \\
\text { relationship }\end{array}$ & $\begin{array}{l}-0.132 \\
(0.173)\end{array}$ & $\begin{array}{c}0.598^{* *} \\
(0.156)\end{array}$ & $\begin{array}{c}0.466^{* *} \\
(0.169)\end{array}$ \\
\hline $\begin{array}{l}\text { Ever in Colonial } \\
\text { relationship }\end{array}$ & $\begin{array}{l}0.668 * * \\
(0.063)\end{array}$ & $\begin{array}{l}0.459 * * \\
(0.049)\end{array}$ & $\begin{array}{l}1.127 * * \\
(0.077)\end{array}$ \\
\hline Observations & 172544 & 172544 & 172544 \\
\hline R-sq & 0.68 & 0.61 & 0.76 \\
\hline
\end{tabular}


Table 3. IV, panel regressions with country fixed effects from 1973-2000

\begin{tabular}{|c|c|c|c|}
\hline \multicolumn{4}{|c|}{ bilateral exports of 148 countries from $1973-2000$} \\
\hline & \multicolumn{3}{|c|}{ IV, Panel Regressions with Country Fixed effects } \\
\hline $\begin{array}{c}\text { Dependent } \\
\text { Variable }\end{array}$ & $\begin{array}{l}\text { logarithm of the } \\
\text { extensive margin }\end{array}$ & $\begin{array}{l}\text { logarithm of the } \\
\text { intensive margin }\end{array}$ & $\begin{array}{c}\text { logarithm of the } \\
\text { export share }\end{array}$ \\
\hline Currency Union & $\begin{array}{c}0.903^{* *} \\
(0.167)\end{array}$ & $\begin{array}{l}-0.082 \\
(0.110)\end{array}$ & $\begin{array}{c}0.821^{* *} \\
(0.182) \\
\end{array}$ \\
\hline Direct Peg & $\begin{array}{l}-0.078 \\
(0.136) \\
\end{array}$ & $\begin{array}{c}0.504^{* *} \\
(0.124)\end{array}$ & $\begin{array}{l}0.425^{* *} \\
(0.170)\end{array}$ \\
\hline Indirect Peg & $\begin{array}{l}-0.039 \\
(0.029)\end{array}$ & $\begin{array}{c}-0.039 \\
(0.023)\end{array}$ & $\begin{array}{l}-0.079 * \\
(0.035)\end{array}$ \\
\hline $\begin{array}{c}\text { Exchange Rate } \\
\text { Volatility }\end{array}$ & $\begin{array}{l}-0.062 * \\
(0.030)\end{array}$ & $\begin{array}{l}0.051 * \\
(0.023)\end{array}$ & $\begin{array}{l}-0.011 \\
(0.036)\end{array}$ \\
\hline $\begin{array}{c}\text { In relative real } \\
\text { GDPpc }\end{array}$ & $\begin{array}{l}0.873 * * \\
(0.031)\end{array}$ & $\begin{array}{l}0.318 * * \\
(0.026)\end{array}$ & $\begin{array}{l}1.192 * * \\
(0.036)\end{array}$ \\
\hline $\begin{array}{l}\text { ln relative } \\
\text { Population } \\
\end{array}$ & $\begin{array}{c}0.641^{* *} \\
(0.033)\end{array}$ & $\begin{array}{c}0.259 * * \\
(0.027)\end{array}$ & $\begin{array}{l}0.900 * * \\
(0.036)\end{array}$ \\
\hline ln Distance & $\begin{array}{c}-0.875^{* *} \\
(0.017) \\
\end{array}$ & $\begin{array}{c}-0.280^{* *} \\
(0.013) \\
\end{array}$ & $\begin{array}{c}-1.155^{* *} \\
(0.019)\end{array}$ \\
\hline $\begin{array}{l}\text { Common } \\
\text { Language }\end{array}$ & $\begin{array}{l}0.339 * * \\
(0.029)\end{array}$ & $\begin{array}{l}-0.009 \\
(0.023)\end{array}$ & $\begin{array}{l}0.330 * * \\
(0.036)\end{array}$ \\
\hline Border & $\begin{array}{l}-0.057 \\
(0.084)\end{array}$ & $\begin{array}{l}0.238 * * \\
(0.056)\end{array}$ & $\begin{array}{l}0.181 * \\
(0.088)\end{array}$ \\
\hline $\begin{array}{l}\text { Free Trade } \\
\text { Agreement }\end{array}$ & $\begin{array}{c}-0.408 * * \\
(0.091)\end{array}$ & $\begin{array}{l}0.514 * * \\
(0.046)\end{array}$ & $\begin{array}{c}0.105 \\
(0.080)\end{array}$ \\
\hline $\begin{array}{l}\text { Currently in } \\
\text { Colonial } \\
\text { relationship }\end{array}$ & $\begin{array}{c}0.026 \\
(0.239)\end{array}$ & $\begin{array}{c}0.627^{* *} \\
(0.190)\end{array}$ & $\begin{array}{c}0.653 * * \\
(0.173)\end{array}$ \\
\hline $\begin{array}{l}\text { Ever in Colonial } \\
\text { relationship }\end{array}$ & $\begin{array}{l}0.685 * * \\
(0.068)\end{array}$ & $\begin{array}{l}0.410 * * \\
(0.052)\end{array}$ & $\begin{array}{l}1.096 * * \\
(0.081)\end{array}$ \\
\hline Observations & 172544 & 172544 & 172544 \\
\hline R-sq & 0.64 & 0.57 & 0.74 \\
\hline
\end{tabular}


Table 4. Panel regressions from 1962-2000

\begin{tabular}{|c|c|c|c|c|c|c|}
\hline \multicolumn{7}{|c|}{ bilateral exports of 148 countries from $1962-2000$} \\
\hline & \multicolumn{3}{|c|}{$\begin{array}{l}\text { Panel Regression with } \\
\text { Country Fixed effects }\end{array}$} & \multicolumn{3}{|c|}{$\begin{array}{l}\text { IV, Panel Regression with } \\
\text { Country Fixed effects }\end{array}$} \\
\hline $\begin{array}{c}\text { Dependent } \\
\text { Variable }\end{array}$ & $\ln \mathrm{EM}$ & $\ln \mathrm{IM}$ & $\operatorname{lnEXshare~}$ & $\ln \mathrm{EM}$ & $\ln \mathrm{IM}$ & lnEXshare \\
\hline $\begin{array}{c}\text { Currency } \\
\text { Union }\end{array}$ & $\begin{array}{c}0.930 * * \\
(0.122)\end{array}$ & $\begin{array}{c}0.028 \\
(0.077) \\
\end{array}$ & $\begin{array}{c}0.958 * * \\
(0.138)\end{array}$ & $\begin{array}{c}0.909 * * \\
(0.124)\end{array}$ & $\begin{array}{c}0.045 \\
(0.079) \\
\end{array}$ & $\begin{array}{c}0.953 * * \\
(0.140)\end{array}$ \\
\hline Direct Peg & $\begin{array}{c}0.064 \\
(0.063) \\
\end{array}$ & $\begin{array}{c}0.194^{* *} \\
(0.053)\end{array}$ & $\begin{array}{c}0.258 * * \\
(0.074)\end{array}$ & $\begin{array}{l}-0,050 \\
(0.102) \\
\end{array}$ & $\begin{array}{c}0.284^{* *} \\
(0.100)\end{array}$ & $\begin{array}{c}0.234 \\
(0.139) \\
\end{array}$ \\
\hline Indirect Peg & $\begin{array}{l}-0.036 \\
(0.021) \\
\end{array}$ & $\begin{array}{l}-0.013 \\
(0.017) \\
\end{array}$ & $\begin{array}{l}-0.048 \\
(0.025) \\
\end{array}$ & $\begin{array}{l}-0.045^{*} \\
(0.022)\end{array}$ & $\begin{array}{l}-0.006 \\
(0.016)\end{array}$ & $\begin{array}{l}-0.050 \\
(0.027) \\
\end{array}$ \\
\hline $\begin{array}{l}\text { Exchange } \\
\text { Rate } \\
\text { Volatility }\end{array}$ & $\begin{array}{c}-0.132 * * \\
(0.031)\end{array}$ & $\begin{array}{c}0.100 * * \\
(0.023)\end{array}$ & $\begin{array}{l}-0.032 \\
(0.036)\end{array}$ & $\begin{array}{c}-0.135 * * \\
(0.031)\end{array}$ & $\begin{array}{c}0.102 * * \\
(0.024)\end{array}$ & $\begin{array}{l}-0.033 \\
(0.036)\end{array}$ \\
\hline $\begin{array}{l}\text { In relative } \\
\text { real GDPpc }\end{array}$ & $\begin{array}{c}0.874 * * \\
(0.031)\end{array}$ & $\begin{array}{c}0.258 * * \\
(0.024)\end{array}$ & $\begin{array}{l}1.132 * * \\
(0.036)\end{array}$ & $\begin{array}{c}0.876^{* *} \\
(0.031)\end{array}$ & $\begin{array}{c}0.258 * * \\
(0.024)\end{array}$ & $\begin{array}{l}1.133 * * \\
(0.036)\end{array}$ \\
\hline $\begin{array}{l}\text { In relative } \\
\text { Population }\end{array}$ & $\begin{array}{c}0.573 * * \\
(0.033)\end{array}$ & $\begin{array}{c}0.166^{* * *} \\
(0.025)\end{array}$ & $\begin{array}{c}0.738 * * \\
(0.036)\end{array}$ & $\begin{array}{c}0.575 * * \\
(0.033)\end{array}$ & $\begin{array}{c}0.164^{* *} \\
(0.025)\end{array}$ & $\begin{array}{c}0.739 * * \\
(0.036)\end{array}$ \\
\hline ln Distance & $\begin{array}{c}-0.831 * * \\
(0.016)\end{array}$ & $\begin{array}{c}-0.273 * * \\
(0.012)\end{array}$ & $\begin{array}{c}-1.104 * * \\
(0.019) \\
\end{array}$ & $\begin{array}{c}-0.832 * * \\
(0.016)\end{array}$ & $\begin{array}{c}-0.272 * * \\
(0.012)\end{array}$ & $\begin{array}{c}-1.104^{* *} \\
(0.019) \\
\end{array}$ \\
\hline $\begin{array}{l}\text { Common } \\
\text { Language } \\
\end{array}$ & $\begin{array}{c}0.327 * * \\
(0.028) \\
\end{array}$ & $\begin{array}{c}-0.004 \\
(0.022) \\
\end{array}$ & $\begin{array}{c}0.322 * * \\
(0.035)\end{array}$ & $\begin{array}{c}0.328 * * \\
(0.028)\end{array}$ & $\begin{array}{l}-0.005 \\
(0.022) \\
\end{array}$ & $\begin{array}{c}0.323 * * \\
(0.035) \\
\end{array}$ \\
\hline Border & $\begin{array}{c}-0.028 \\
(0.079) \\
\end{array}$ & $\begin{array}{c}0.178 * * \\
(0.054)\end{array}$ & $\begin{array}{c}0.150 \\
(0.083) \\
\end{array}$ & $\begin{array}{l}-0.028 \\
(0.079) \\
\end{array}$ & $\begin{array}{c}0.178 * * \\
(0.053)\end{array}$ & $\begin{array}{c}0.150 \\
(0.083) \\
\end{array}$ \\
\hline $\begin{array}{l}\text { Free Trade } \\
\text { Agreement }\end{array}$ & $\begin{array}{c}-0.198 * \\
(0.090) \\
\end{array}$ & $\begin{array}{c}0.494^{* *} \\
(0.046) \\
\end{array}$ & $\begin{array}{c}0.296 * * \\
(0.075)\end{array}$ & $\begin{array}{c}-0.192 * \\
(0.090) \\
\end{array}$ & $\begin{array}{c}0.489 * * \\
(0.046)\end{array}$ & $\begin{array}{c}0.297 * * \\
(0.075) \\
\end{array}$ \\
\hline $\begin{array}{l}\text { Currently in } \\
\text { Colonial } \\
\text { relationship }\end{array}$ & $\begin{array}{c}0.006 \\
(0.191)\end{array}$ & $\begin{array}{c}0.388 \\
(0.199)\end{array}$ & $\begin{array}{c}0.394 \\
(0.235)\end{array}$ & $\begin{array}{c}0.019 \\
(0.197)\end{array}$ & $\begin{array}{c}0.378 \\
(0.203)\end{array}$ & $\begin{array}{c}0.397 \\
(0.234)\end{array}$ \\
\hline $\begin{array}{c}\text { Ever in } \\
\text { Colonial } \\
\text { relationship }\end{array}$ & $\begin{array}{c}0.674 * * \\
(0.060)\end{array}$ & $\begin{array}{c}0.472 * * \\
(0.047)\end{array}$ & $\begin{array}{c}1.146 * * \\
(0.073)\end{array}$ & $\begin{array}{c}0.694^{* *} \\
(0.063)\end{array}$ & $\begin{array}{c}0.456 * * \\
(0.049)\end{array}$ & $\begin{array}{l}1.150 * * \\
(0.077)\end{array}$ \\
\hline Observations & 204858 & 204858 & 204858 & 204858 & 204858 & 204858 \\
\hline R-sq & 0.62 & 0.57 & 0.73 & 0.62 & 0.57 & 0.73 \\
\hline
\end{tabular}

